\title{
Engaging Rural School parents in School Governance: The Experiences of South African School Principals
}

\author{
Dr M. A. N. Duma \\ University of Zululand, KwaDlangezwa . 3886, Republic of South Africa \\ Email:dumam@unizulu.ac.za
}

\section{Doi:10.5901/mjss.2014.v5n27p460}

\begin{abstract}
The aim of this article is to explore the experiences of principals on rural school parent engagement in governance of schools. Apart from a literature review on parent engagement in school governance, this article reports on a study in which empirical investigation based on quantitative research paradigm was used to collect data from rural school principals. The literature findings revealed that engaging parents in school governance is a critical component of education in South Africa. The study further on revealed that empirical findings elicited that rural school principals would like parents to have a significant role to play in school governance. The study is concluded by the submission that it is essential for parents in school governance to be given necessary training so that they can have a working knowledge of school governance activities.
\end{abstract}

Keywords: parent engagement, parent governors, principals, rural schools, school governance

\section{Introduction}

Mechanisms to engage parents in the governance of schools are employed globally as a form of democratising education (Mncube, 2005). Duma (2009) observed that that school principals and parents often have uncertainties about the roles that the each should play in the governance of schools. Some principals love to have parents intricately involved in the governance of their schools, while others feel that too much parent engagement in the governance of schools violates their sense of professionalism. Principals with such a mind-set, tend to blame parents for prying in the school governance processes. They are reluctant to comprehensively engage parents in school governance. Mkentane (2003) argues that if school principals ignore the strengths that the father and mother figures can bring to schools, valuable resources that could have a positive impact on the school governance activities are neglected.

In South Africa, before 1994, the Apartheid government had excluded the majority of citizens from genuine engagement in the governance of schools. In 1996, the new democratic South African government established the South African Schools Act (Act No 84 of 1996) which for the first time, provided for the need of parent engagement in school governance matters (RSA, 1996). This Act mandated that all schools in South Africa must have democratically elected school governing bodies composed of teachers, non-teaching staff, parents, and learners. This Act furthermore vested the governance of every public school in the hands of parents through the establishment of school governing bodies for all public schools whose functions include, among others, recommending the appointment of principals, teachers and non-teaching staff, deciding on the language policy of the school, control and maintenance of the school property, and determining school fees (RSA, 1996).

Various studies have been carried out on the functioning of school governing bodies in South Africa (Karlsson, 2002; McPherson, 2000; Carrim \& Tshoane 2000; Heystek, 2004; Martin \& Holt, 2002). However, little research has been conducted on the experiences of rural school principals in engaging parents in school governance.

Consequently, the aim of the article is to explore the experience of rural school principals on parent engagement in school governance, problems encountered by rural school principals when attempting to engage parents in school governance and the suggestions they have on encouraging the effective parent engagement in school governance.

\section{Literature Review}

\subsection{Discussion of democratic principles and practices}

The philosophy underpinning this paper is a democratic theory of education. Mncube (2008) contends that a democratic 
theory of education was concerned with the process of "double democratisation", the synchronized democratisation of both education and society. On the contrary, without a more democratic system of education, the development of a democratic society was unlikely to take place. Mncube (2009) further on declares that there is now a significant amount of international and comparative literature on democratic education, which includes the many arguments supporting it, alluding to Murphy, 2006; Davies and Kirkpatrick, 2000; and Harber, 2004 as examples.

Emphasising the need for the practice of democracy in schools, Mncube (2008) suggests that some values, such as democracy, tolerance and responsibility, grow only as one experience them. Therefore schools need to perform what they seek to endorse. Mncube (2008) further on asserts that democratic schools and democracy itself do not grow by chance, but they result from explicit attempts by educators, and thus schools, to put in place arrangements and opportunities that will bring democracy to life. Therefore, a democratic school is one that allows all stakeholders to participate in deliberations dealing with the school governance, where they are prepared to live in democracy through the acquisition of suitable knowledge, skills, attitudes and behaviours. In terms of this article, these skills, values, and behaviours are obtained through active democratic involvement of parents in school governance.

Democratic theories also share the view that each participant carries elementary rational capacities that are sufficient to judge the conduct of the organisation. For such judgments to have a meaning, participants are expected to be free in several important respects; they must be free regarding such matters as speech, making opinions and taking decisions. Duma (2010) posits that democratic norms mandate inclusion as a criterion of political legitimacy. And democracy implies that all members of the organisation are included equally in the decision-making process and, as such, these decisions would be considered by all as legitimate.

In this paper democratic theory of education premises democratic school governance in which parent engagement in school governance operations is indispensable. The establishment of the school governing bodies in South Africa increased the parent engagement in school governance by establishing roles and developing trust relationships with new partners, namely the school and the family. The school governing bodies give parents input at the school management level and create a greater sense of participation in school governance matters (Duma, Kapueja \& Khanyile, 2011).

\subsection{A brief history of parent engagement in schools in South Africa}

During the apartheid era, parent engagement in school governance was arranged according to race distinctions. Many Commissions were appointed to deal with parent engagement in schools and recommended the establishment of school committees so that Black parents could share, as far as possible, in the life and control of the schools in which their children are enrolled (Seroto, 2004). For instance, the 1981 De Lange Commission Report recommended that autonomy be given to schools so that parents would have a major share in decision-making processes. The Report, however, did not gain the support of the Black youth. By the end of 1985, Black schooling was in a crisis (Seroto, 2004). The Soweto Civic Association formed the Soweto Parents' Crisis Committee, which in 1986 formed the National Education Crisis Committee (NECC) that introduced the concept of People's Education as an alternative education for Black children (Duma, 2010). Later on, the 1988 Education Laws Amendment Act allowed for the establishment of school committees, comprising the farm owners and parents (Mkentane, 2003). It is worth noting that little use was made of these concessions, because the Right Wing members of Parliament were against them (Seroto, 2004). In a nutshell, one can say that the legitimate role of Black parents in school governance was undermined.

It was only after the demise of Apartheid in 1994 that the new South African democratic government promulgated the National Education Policy Act (Act No. 27 of 1996) which outlined the organisation, management, and governance of schools. It stipulated that education policies have to ensure broad public participation in the development of the education system and the representation of stakeholders in the governance of all aspects of the education system (Oosthuizen, 2004). In 1996, the state published an Education White Paper 2 (General Notice 130 of 1996) which introduced a school governance structure that involves all the stakeholder groups. This document outlined the policy of the government on the governance of schools, and the development of capacity for school leadership throughout the country. The White Paper incorporated a major role for parents in school governance. From this White Paper originated the South African Schools Act of 1996, which mandated that all schools in South Africa must have democratically elected school governing bodies. The core of the South African Schools Act was to transform education away from the iniquitous policies of the past. Its main thrust was the normalisation of the South African education system; the advancement of the democratic transformation of the country; the combating of racism, sexism and all forms of unfair discrimination; the promotion of the rights of learners, school principals and parents and most significantly, the participation of parents in school governance (RSA, 1996). This Act furthermore vested the governance of every public school in the hands of parents. 
This paper addresses the question of how rural school principals experience increased parent engagement in school governance and what support they require for this change. Through data collection, in the form of questionnaires the experiences of rural school principals regarding parent engagement were uncovered.

\section{Research Methodology}

To address the research problem, both literature study and empirical investigation based on quantitative research design were undertaken. The researcher consulted literature which is relevant to the topic. This was done to provide a critical synthesis of what has already been written on the topic.

\subsection{Quantitative Research Paradigm}

A survey to gather questionnaire-based data in a real-life setting was used in the study. The research design included the delimitation of the field of survey, the selection of respondents (size of the sample and sampling procedures), the research instruments, namely the questionnaires, a pilot study, the administration of the questionnaires, and the processing of data.

\subsection{Population and Sampling}

The researcher used the simple random sampling method to select thirty rural school principals in each circuit of Sisonke and UMgungundlovu Districts as respondents. Since these two districts have eight circuits, two hundred and forty rural school principals were selected as respondents. This method was favoured for its simplicity, unbiased nature, and its closeness to fulfilling the major assumption of probability, namely that each element in the population stands an equal chance of being selected (Kumar, 2014). For ethical reasons, permission to conduct research in schools was sought from the relevant district offices.

\subsection{Instrumentation}

The questionnaire was used as research instrument. As Kumar (2014) maintains that questionnaires permit anonymity, preclude possible interviewer biases and permit a respondent sufficient time to consider answers before actually answering. Data provided by questionnaires can be more easily analysed and interpreted than the data obtained from verbal responses and lastly, questionnaires can elicit information that cannot be obtained in other methods.

\subsection{Format of the Questionnaire}

The questionnaire was divided into three sections, with each section focusing on the aims of the study. Section 1 dealt with the biographic and general information. This section provided the researcher with an understanding and knowledge of the respondents. Section 2 had closed questions focusing on the rural school principals' experiences on parent engagement in school governance. The respondents were asked to rate their responses according to the following scale: Yes, Unsure, No. Section 3 consisted of open-ended questions, wherein rural school principals had to mention problems they encounter when attempting to engage parents in school governance and had to suggest what could be done to improve effective parent engagement in school governance.

\subsection{Administration of the Questionnaires}

The researcher conducted a pilot study in eight rural schools. These schools were part of the general population from which the sample was drawn, but not part of the sample itself. No inherent weaknesses were discovered in the questionnaires and the data solicited confirmed the questionnaires' validity and reliability, consequently there was no need to modify the questionnaires. In the main study, 240 rural school principals were randomly selected and were requested to complete their questionnaires.

The first sample population responses were 188 (78\%) respondents. After the follow-ups, 24 respondents returned the completed questionnaires to make total responses of $212(88 \%)$ respondents. That represented a satisfying response. 


\subsection{Data Processing}

After all the questionnaires had been received, the important task was then to reduce the mass of data obtained to a format suitable for analysis. The respondents' responses were coded and frequency distributions were generated.

\section{Findings and Discussion}

\subsection{General and Biographical profile of the Respondents}

When the item of rural school principals' qualification was analysed, it was realised that all the respondents had fully completed the information regarding general and biographical data.

Table 1. Education background of school principals

\begin{tabular}{|l|c|c|}
\hline Education background of learner governors & $\mathbf{N}$ & $\%$ \\
\hline Below Matric (Grade 12) & 0 & 0 \\
\hline Matric ( Grade 12) & 0 & 0 \\
\hline Matric + 1 ( M+1) & 25 & 12 \\
\hline Matric + 2 (M+2) & 42 & 20 \\
\hline Matric +3 and above & 145 & 68 \\
\hline Total & $\mathbf{2 1 2}$ & 100 \\
\hline
\end{tabular}

This table revealed that a high proportion of rural school principals (68\%) had good academic qualifications. This shows that the education level of the principal population in rural schools is improving. This high qualification rate can help rural school principals to empower parents in school governance with capacity building skills to render effective school governance activities

\subsection{Rural school principals 'experiences on parent engagement in school governance}

In this section, the school principals were required to indicate their experiences on parent engagement in school governance.

Table 2: Rural school principals 'experiences on parent engagement in school governance

\begin{tabular}{|l|c|c|c|c|c|}
\hline Items & & Yes & Unsure & No & Total \\
\hline \multirow{2}{*}{ The role of parents in school governance is indispensable } & $\mathrm{N}$ & 184 & 28 & 0 & 212 \\
\cline { 2 - 5 } & $\%$ & 87 & 13 & 0 & 100 \\
\hline Schools fare better when they draw on the expertise and assistance of & $\mathrm{N}$ & 191 & 0 & 21 & 212 \\
\cline { 2 - 5 } parents & $\%$ & 90 & 0 & 10 & 100 \\
\hline Parents in school governance interact with principals regularly & $\mathrm{N}$ & 42 & 0 & 170 & 212 \\
\cline { 2 - 5 } on school governance matters. & $\%$ & 20 & 0 & 80 & 100 \\
\hline Parents in school governance interfere in curriculum issues that they do & $\mathrm{N}$ & 184 & 0 & 28 & 212 \\
\cline { 2 - 5 } not have any knowledge on. & $\%$ & 87 & 0 & 13 & 100 \\
\hline Parents in school governance cause some principals to feel that they & $\mathrm{N}$ & 127 & 21 & 64 & 212 \\
\cline { 2 - 5 } lose control over their work & $\%$ & 60 & 10 & 30 & 100 \\
\hline Parents in school governance recommend to the Head of Department & $\mathrm{N}$ & 212 & 0 & 0 & 212 \\
\cline { 2 - 5 } the appointment of educators at the school & $\%$ & 100 & 0 & 0 & 100 \\
\hline Parents in school governance support the principal, educators and other & $\mathrm{N}$ & 42 & 0 & 170 & 212 \\
\cline { 2 - 5 } staff of the school in the performance of their professional functions & $\%$ & 20 & 0 & 80 & 100 \\
\hline Parents in school governance are effective in instilling discipline among & $\mathrm{N}$ & 10 & 32 & 170 & 212 \\
\cline { 2 - 5 } students & $\%$ & 5 & 15 & 80 & 100 \\
\hline \multirow{2}{*}{ Parents in school governance ensure that students attend school } & $\mathrm{N}$ & 0 & 0 & 212 & 212 \\
\cline { 2 - 5 } & $\%$ & 0 & 0 & 100 & 100 \\
\hline
\end{tabular}

This table focused on rural school principals 'experiences on parent engagement in school governance. The respondents 
were asked to rate their responses according to the following scale: Yes, Unsure, and No.

\subsubsection{The role of parents in school governance is indispensable}

In Table 2, there was congruence among the respondents that role of parents in school governance is indispensable. Monadjem (2003) notes that many governments and districts have recognised the need for legislations to ensure that parents are intensively involved in school governance. This recognition is based on the realisation that parents have a right to play an active role in their children's education, and that parents may help alleviate some of the problems faced by learners.

This positive support for parent engagement in school governance indicates that the respondents understand the fact that parents are integral to schooling. Duma (2009) observed that parents are first-line clients of the school. The respondents, furthermore, appreciated the fact that the demand for democracy and participation in the South African education system has a long history, stretching from colonial times in the $17^{\text {th }}$ century to the intense and bitter student protests in the eighties (Nongqauza, 2004). The involvement of parents in school governance is essential in running a successful school as they are empowered to participate in decision-making processes.

\subsubsection{Schools fare better when they draw on the expertise and assistance of parents}

The majority of the respondents (90\%), as indicated in Table 2, agreed that schools fare better when they draw on the parents' expertise and assistance. This impressive support for this item indicates that rural school principals value engaging parents in the governance of their schools. Duma (2010) also confirms this, when he asseverates that every research study on parent involvement in education has shown that parent participation increases student achievement.

\subsubsection{Parents in school governance interact with principals regularly in school governance matters.}

Table 2 revealed that a majority of the respondents (80\%) indicated that parents in school governance do not regularly interact with principals in school governance matters. This implies that most schools do not really use parent governors to promote democratic participation. The majority of schools are still authoritarian and reinforce passive subordination amongst school governing bodies. The policy maintains that parent stakeholders are important instruments for school governance.

\subsubsection{Parents in school governance interfere in curriculum issues that they do not have any knowledge on.}

Table 2 further on revealed that a high proportion of respondents (87\%) indicated that parents in school governance interfere in issues that they do not have any knowledge on, such as curriculum matters. Parent stakeholders play a pivotal role in democratising the education landscape, as they are the structures that represent the voice of the parents. They provide space for parents to articulate their needs, concerns, aspirations as well as present their wishes to the schools. They provide parents with an opportunity to participate in school governance and to participate in appropriate decision-making. However, the respondents feel that parents have no informed knowledge about curriculum matters.

\subsubsection{Parents in school governance cause some principals to feel that they lose control over their work}

It seems that school principals in this survey were concerned that parents in school governance cause them to feel that they lose control over their work. As it can be seen from Table 3, a majority of the respondents (60\%) indicated that these parents cause some of them to feel that they lose control over their work. This is not surprising because under the Apartheid Education Departments, the idea of parent participation in the governance of rural schools especially in the farm schools was considered as an absurdity of the first order. Decisions about education lay squarely in the domain of principals, farm owners and school inspectors (Duma, 2010). So, involving parents in school governance would tantamount to above mentioned stakeholders losing their status and influence in schools.

\subsubsection{Parents in school governance recommend to the Head of Department the appointment of educators at the school}

Table 2 also revealed that all respondents (100\%) indicated that parents in school governance recommend to the Head of Department the appointment of educators at the school. This unanimous agreement of the respondents to this item might 
be caused by the fact that the selection of human resources before 1994 had been the exclusive right of the school inspectors, however the new dispensation brought about the decentralization and devolution of authority to parents.

\subsubsection{Parents in school governance support the principal, educators and other staff of the school in the performance of their professional functions}

Again, Table 2 revealed that a high proportion of the respondents (80\%) indicated that parents in school governance do not support the principal, educators and other staff of the school in the performance of their professional functions. This is a disturbing response since Section 20 (1) of the South African Schools Act clearly states that it is the duty of the parents in school governance to support the principal, teachers and other staff of the school in the performance of their professional functions (RSA 1996). Nongqauza (2004) confirms that parents should be drawn into school activities not only in terms of auxiliary tasks, but also in the school management functions of planning, financing, administration and control of the school's property.

\subsubsection{Parents in school governance are effective in instilling discipline among students}

Table 2 once more revealed that a high proportion of the respondents (80\%) indicated that parents in school governance are not effective in instilling discipline among students. This response is also disturbing because it indicates that parents as primary teachers, have a responsibility to mould their children to perfection, on the other hand, the response may imply that since the banning of corporal punishment in schools, the schools find themselves powerless to instil discipline, as Section 10 of the South African Schools Act stipulates that no person may administer corporal punishment at a school to a student and any person who contravenes this section is guilty of an offence and liable for conviction which could be imposed for assault (RSA, 1996). Potgieter, Mosoge, and Mothaba (1997) advance that good school discipline is an important feature of effective schools. To achieve good discipline, every school must have a code of conduct, which must be adopted by parents in school governance.

\subsubsection{Parents in school governance ensure that students attend school}

In conclusion, Table 2, also revealed that all respondents (100\%) indicated that parents in school governance do not ensure that students attend school. This is also worrying because the South African Schools Act stipulates that every parent must ensure that every student for whom he or she is responsible for attends a school from the first school day of the year in which such student reaches the age of seven years until the last school day of the year in which such student reaches the age of fifteen years or the ninth grade, whichever occurs first (RSA, 1996). In this instance, the parent is legally bound to enforce student attendance in school.

\subsection{Problems encountered by rural school principals when attempting to engage parents in school governance.}

This section was an open-ended question, where school principals were required to mention the problems they encounter when trying to engage parents in the governance of their schools. In analysing the responses, the problems were ranked in the order of frequency as follows:

Parents participating in school governance are:

- Either illiterate or semi- literate (88\%).

- No experience in school governance (79\%).

- Irregularly attendance of school governance meetings (65\%).

- Negative attitudes towards school principals (64\%).

\subsection{Rural school principals' suggestions on improving parent engagement in the governance of their schools}

In another open-ended question, school principals were required to make suggestions on what can be done to improve parent engagement in school governance. In analysing the responses, the suggestions were ranked in the order of frequency as follows:

- Parents in school governance should be literate (88\%)

- The Department of Education to introduce literacy classes for parent in school governance (84\%) 
- Training workshops should be organised for parents in school governance (77\%)

\section{Concluding Remarks}

This study explored the views held by rural school principals on parent engagement in school governance. Although the participants were supportive of parent engagement in school governance, their views also illuminate challenges associated with implementing school governance activities. One of the great challenges is the illiteracy rate of parents in school governance, who should be playing a significant role in school governance activities. However, they lack the knowledge and the training to do so. It is essential for them to be given the necessary training, which should include the opportunity to acquire the necessary knowledge so they would be in a position to participate meaningfully in the school governance activities.

\section{References}

Carrim N \& Tshoane M (2000). The Holy State? Values, Legitimisation and Ideological Closure in South African Education. Quarterly Review of Education and Training in South Africa, 7:12-29.

Davies, L. \& Kirkpatrick, G. (2000). The EURIDEM Project: A Review of Learner Democracy in Europe. London: Children's Rights Alliance.

Duma M. (2008). Involvement of parent governors in the administration of farm schools. Interkulurell und Global, 3 (4): 80-98.

Duma M. (2009). Parent Involvement in school governance of public schools on private properties. Journal of Educational Studies, 8 (4): 89-102.

Duma M. (2010). An investigation into Rural School Parent governors' Understanding of the Legislations that Impact on School Governance. International Journal for Cross-Disciplinary Subjects in Education (IJCDSE), 1 (1):183-198.

Duma, M., Kapueja,I. \& Khanyile P. (2011). Educators' Experiences on the Role of Parents in the School Governing Bodies of Rural Schools. American International Journal of Contemporary Research, 1 ( 3) : 44-52.

Harber, C. (2004). Schooling as Violence. London: Routledge Falmer.

Heystek, J. (2004). School Governing Bodies-the principal's burden or the light of his or her life? South African Journal of Education, $24(4): 308-312$.

Karlsson J (2002). The role of democratic governing bodies in South African schools Comparative Education, 38 (3): 327-336.

Kumar R (2014). Research Methodology: As Step-by-Step Guide for Beginners. New Delhi: SAGE Publications.

McPherson G. (2000). Governance in Public Schools: Four Case Studies. Education Monitor, 11:1-8.

Martin J \& Holt A (2002). Joined-up Governance: Making Sense of the Role of the School Governor. Stretham: Adamson Books

Mkentane, M. (2003). The role of School governing bodies in transforming education in South Africa: a study of selected secondary schools in the Tsomo district of Eastern Cape Province, M Ed diss., Stellenbosch :University of Stellenbosch.

Mncube V (2005). School Governance in the Democratisation of Education in South Africa: The Interplay Between Policy and Practice. PhD thesis., London: University of Birmingham, UK.

Mncube, V. (2008). Democratisation of education in South Africa: issues of social justice and the voice of learners. South African Journal of Education. 28 (1): 129-143.

Mncube, V. (2009). Perceptions of the principal's role in democratic school governance in South Africa .Journal of Educational Administration and History. 41(1): 29-43.

Monadjem, L. (2003). The Development of a Programme for Parental Involvement in Senior Primary Schools in Swaziland. PhD diss., Pretoria: University of South Africa.

Murphy, M. (2006) Every Child Has a View. Education Guardian 28/11.

Nongqauza, A. (2004). The Role of a Principal in an Academically Successful Farm School. Masters diss., Cape Town : Rhodes University.

Oosthuizen, I. J. (2004). Aspects of Educational Law. Pretoria: Van Schaik.

Potgieter, J. Mosoge, J \& Mothaba, M (1997). Understanding the South African Schools Act: What Public School Governors Need to Know? Pretoria: Government Printers.

Republic of South Africa. (1996). South African Schools Act. : Act No 84 of 1996. Pretoria: Government Printers.

Seroto, J. ( 2004). The Impact of South African Legislation (1948-2004) on Black Education in Rural Areas: A Historical Educational Perspective. PhD diss., Pretoria: University of South Africa. 